\title{
María en trampantojo. A propósito de las imágenes marianas en la España del siglo XVII
}

\author{
Cécile Vincent-CASsY \\ Université Paris 13
}

\begin{abstract}
En este artículo tratamos de las imágenes marianas de culto local, cuyas tallas son, en muchos casos, «imágenes de vestir», con el cuerpo sin esculpir debajo del vestido y del manto. Estas imágenes se distinguen las unas de las otras por sus atuendos. Tras haber expuesto la complejidad teológica y antropológica de la imagen mariana en España en la época postridentina, exponemos la idea de que estas imágenes, designadas como «retratos», fueron un tema recurrente de las comedias del XVII, constituyendo un auténtico subgénero teatral. La conciencia de la tensión existente en las imágenes entre materialidad y referencialidad, llegó a un grado de sofisticación muy alto en los llamados «trampantojos a lo divino», como el cuadro que realizó Tomás Yepes de la Virgen de los Desamparados en 1644 .
\end{abstract}

Keywords: Imagen, Virgen María, comedia religiosa, trampantojo a lo divino, retrato.

En Ce que nous voyons, ce qui nous regarde, en español «Lo que vemos, lo que nos mira», Didi-Huberman quiso interrogarse sobre la escisión del ver, sobre la pareja ontológica entre lleno y vacío que reside en la experiencia del ver, sobre la pérdida (y sus derivaciones de ausencia o muerte) que implica la presencia visible de un objeto. Para explicar su cuestionamiento, en la introducción toma el ejemplo de la experiencia que todo ser tiene ante la tumba, llena de lo que ya no existe (Didi-Huberman I992: I8 y sg.). Partiendo de esta reflexión sobre la mirada, encontramos un formidable eco en un contexto que, a priori, se presenta como muy dispar y muy remoto al que desarrolla el autor. Ciertamente, desde la perspectiva antropológica, indispensable para abordar el uso de las imágenes religiosas, la experiencia que un fiel tenía en el Siglo de Oro español frente a las imágenes marianas que, esculpidas en madera, se entregaban al culto en sus capillas y altares, en un sinfín de espacios de devoción, por toda la península ibérica, era parecida a la que evoca Didi-Huberman en su libro. El juego entre materialidad y referencialidad que se desarrolló en estas imágenes sagradas fue viva expresión de la ambivalencia de la relación que el mundo católico tenía con la imago․ Se

I Es un tema que han abordado algunos historiadores del arte en las últimas décadas. Especialmente Felipe Pereda en Las imágenes de la discordia. Política y poética de la imagen sagrada en la España del 40o, en particular pp. 88-98, y en su reciente Crimen e ilusión. El arte de la verdad en el Siglo de Oro, en que el autor indaga en el proceso por el cual los espectadores de las imágenes se convertían ante ellas en los «testigos» de su verdad y, a la vez, de su engaño. 
expresó a través de una nutrida literatura que enaltecía el poder de intercesión de tal o cual «retrato» de la Virgen, situado en tal o cual santuario. Eran tratados de defensa de las imágenes publicados en el siglo XVII que contaban la leyenda de su hallazgo y valorizaban sus episodios milagreros. Una de las primeras obras impresas de este tipo fue la que publicó el valenciano Jaime Prades en 1597 en honor a la imagen de la Fuente de la Salud, Historia de la adoración y uso de las santas imágenes y de la imagen de la Fuente de la Salud (Valencia, Felipe Mey).

En aquel contexto, las tallas de madera o de papel, adornadas y vestidas, se sustituían, en el régimen del ver, a la figura única e invisible de la Virgen María. Dicho de otro modo, en estas múltiples imágenes se encarnaba su figura. Para designarlas se usa el término de «retratos». Muchas de ellas, que hoy en día siguen siendo objetos de culto, son imágenes de vestir: por dentro no son más que un trozo de madera sin esculpir; por fuera, solo están pintadas su cara, con rasgos a veces bastante esquemáticos, y sus manos, igualmente enjoyadas. De alguna manera, al igual que en la tumba evocada por Didi-Huberman, lo que queda, y cuenta, es la envoltura; lo que se impone al espectador-fiel es el desbordamiento de los ornamentos, la acumulación y la variedad de los mantos de la Virgen, sus coronas y atuendos de todo tipo, que «nos habla de lo que no está» (Didi-Huberman I992: I5). Un paradigma podría ser la Virgen de los Desamparados de Valencia, reconocible por los innumerables exvotos que cuelgan de su manto. En todos los casos de culto mariano, los ornamentos de las imágenes invaden y organizan por un lado el espacio devocional, y por otro el tiempo cotidiano del devoto, pues los atuendos varían en función de la liturgia ordinaria y extraordinaria del año. Todos los signos exteriores de los que se adornan las tallas permiten individualizar y distinguir a las Vírgenes las unas de las otras.

En el siglo XVII español, es decir en la época postridentina, como es de esperar, la naturaleza material de las imágenes marianas, atacada por los Reformados, planteó un problema de orden teológico. Por contradecir, al menos en apariencia, su naturaleza referencial, representativa, produjo un intenso debate dentro de la Iglesia católica. El problema no era exclusivo de la Virgen María. También afectaba a Cristo y a los santos. Dentro de este marco, se llegó a afirmar la idea de que la eficacia y la potencia de tal o cual imagen era mayor que la de su original. Por ejemplo, en el texto de un dominico de finales del XVII, se encuentra esta afirmación a propósito del fundador de la orden de predicadores: «Parece mas poderoso, y mayor Santo Domingo en su Imagen que en su original» (Martínez de Llamo I682: 224).

Cuando los textos trataban de las esculturas de madera de la Virgen con el Niño, llama aún más la atención que pudieran defender el concepto de que estas imágenes estaban hechas a semejanza de la Virgen María a pesar de que su apariencia fuera desconocida, y que ella misma aprobaba, por su 
intervención milagrosa, el uso y devoción de estas imágenes. Un ejemplo muy claro es el «retrato» de la Virgen del Sagrario de Toledo, cuya leyenda, repetida a principios del siglo XVII, contaba que la imagen venerada en la catedral primada había sido «abrazada» por la Virgen en el momento de la Descensión, después de haber impuesto la casulla a San Ildefonso².

Puede parecer sorprendente que la materialidad de las imágenes de culto se asumiera tanto después de los ataques protestantes a las prácticas supersticiosas a las que estas daban lugar. Se suele pensar que la última sesión del concilio de Trento, el 2 de diciembre de 1563, afirmó, sin más, la esencia referencial de las imágenes. Al contrario, veremos que en la época postridentina la conciencia de la índole paradójica de las imágenes locales fue plena entre los autores católicos, y fue incluso un argumento para defenderlas.

Quiero aquí mostrar que la relación entre lo material, lo visible, de estas Vírgenes talladas, y su prototipo, es decir la figura invisible de la Virgen María, fue, en el siglo xVII español, tema de una investigación artística y literaria muy compleja y refinada. Veremos que llegó a un punto álgido en un cuadro de Tomás Yepes (también ortografiado Hiepes, Valencia h. I6Io-Valencia, I674) de I644 que es, según expresión de Alfonso Emilio Pérez Sánchez, un «trampantojo a lo divino» (Pérez Sánchez 1995: 139), llevando a las últimas consecuencias la índole paradójica de la imagen, fuera esculpida o pintada (fig. I). Incluso veremos que siendo las leyendas de imágenes un tema predilecto de la literatura religiosa, fuera hagiográfica o sermonaria, llegaron a constituir un argumento teatral, forjando lo que creo es un subgénero de comedias religiosas: las comedias de imágenes milagrosas.

2 A principios de I6I6, el jesuita Francisco Portocarrero dio a las prensas de Luis Sánchez, en Madrid, su obra titulada Libro de la Descensión de nuestra Señora a la santa Yglesia de Toledo, y vida de San Ilefonso Arçobispo della. En ella, el autor hilvanaba una demostración de la antigüedad de la imagen conocida como de Nuestra Señora del Sagrario, de la que afirmaba que estaba conservada en Toledo desde el siglo vi, y no había sido transportada a Asturias junto a otras santas reliquias en los tiempos de gobierno musulmán. «Su antigüedad es tanta», confesaba Portocarrero, «que no he podido averiguar en que tiempo, ni que artifice la labrò». Pasaba a describirla como «de vulto labrado de talla y madera, vestida de plata con una orla de oro con piedras. Tiene el niño (que tambien es de bulto) vestido de la misma forma que la imagen. Mira a la Madre santissima, y con la mano echa la bendicion al pueblo». La Virgen del Sagrario es pues una sencilla talla de madera, que no es particularmente hermosa, y hoy en día se data del siglo XII — y ha sido revestida de plata en el siglo XV (I465) —. Pero para Portocarrero esta Virgen tenía un valor particular: según la leyenda revitalizada después del concilio de Trento en los entornos humanistas católicos de la ciudad, se trataba de la imagen ante la cual rezaba san Ildefonso cuando se le apareció la Virgen y le impuso la casulla. 


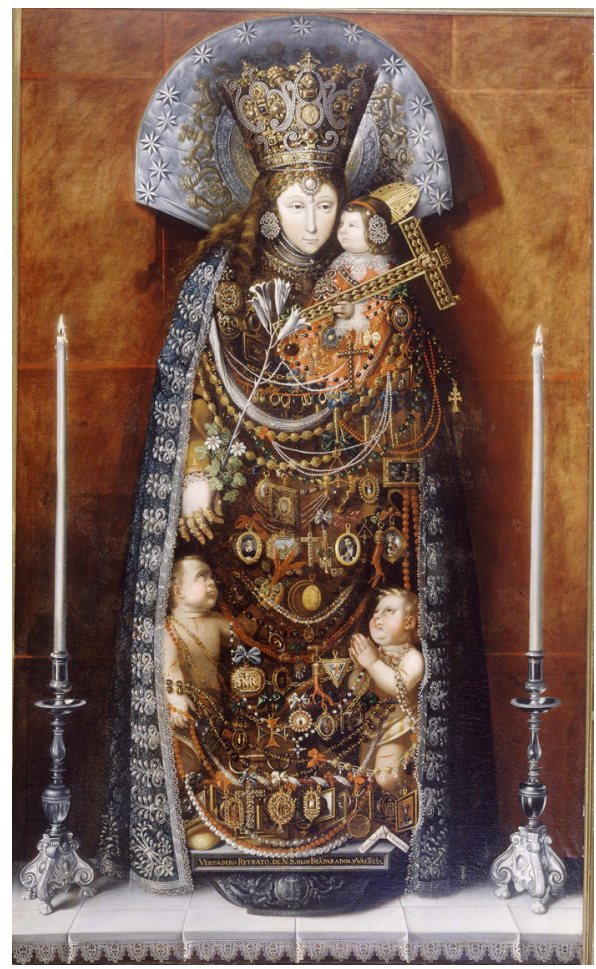

Fig. I. Cuadro de Tomás de Yepes, I644.

\section{Escisión del ver en las imágenes marianas milagrosas}

En España son innumerables las imágenes marianas que podemos citar: la Virgen de Atocha, la Virgen del Pilar, la Virgen de los Reyes, la Virgen de la Regla, la Virgen de Valvanera, la Virgen del Olivar, de la Peña, de Guadalupe, etc. Basándonos en la contribución de Honorario Velasco a la excelente obra sobre la Religiosidad popular que publicaron Carlos Álvarez Santaló, María Jesús Buxó i Rey y Salvador Rodríguez Becerra en 1989, podemos decir que la imagen representa el vínculo con la persona sobrenatural que tiene una comunidad concreta: la imagen es una «concreción» de lo sagrado (Velasco 1989: 402). Como apuntábamos antes, lo que las individualiza son sus atuendos, algo que se intentó regular después del concilio de Trento en los distintos sínodos, como el de Orihuela, en I60o:

Hay que dolerse de que en las iglesias, mientras se celebran las procesiones, las imágenes de los santos y mucho más de la Beatísima Virgen, sean ador- 
nadas con una belleza tan desvergonzada y un esplendor tan mundano y sean compuestas con tanto adorno y tocados de mujer, con vestidos de seda según la costumbre de las mujeres profanas... Mandamos que desde ahora no sean vestidas de este modo las imágenes según la costumbre de otras mujeres, peinadas con el cabello rizado en figura icónica o con vestido recibidos en préstamo de mujeres profanas, ni aliñadas con hábito secular (Saravia I960: I29).

Se expresa aquí la problemática escisión del ver, cuestionada por DidiHuberman: lo que hay «dentro» de la imagen, es decir lo que no es accesible a la vista, desaparece debajo de que lo que está sobre o fuera de la imagen, lo que la adorna. La imagen está cubierta de relicarios, joyas y exvotos. De este modo lo exterior, todo lo que los devotos colocan, cuelgan, acumulan sobre ella, cobra una importancia esencial. La materialidad de la talla escultórica se extiende, y la desborda. La Virgen de los Desamparados, antes citada, es paradigmática de esta constatación.

Sin embargo, remitiéndonos a las categorías fijadas por los teólogos cristianos desde la Edad Media, diríamos que estas esculturas se relacionan más con la imago que con el vestigium. Su semejanza con el prototipo es lejana y arquetípica (una mujer joven con un niño). Su relación con lo sagrado se expresa más bien a través de los testimonios de su intercesión a favor de los fieles: las joyas, etc. Su eficacia es visible a través de estos objetos colgados de su manto, es decir la relación entre la imagen visible y el ser invisible. Es lo que prueba la verdad de su intercesión para una comunidad que la adorna y la enjoya.

La imagen se relaciona también, como ya apuntado, con una leyenda local. Hororario Velasco subraya que: «el lugar es la determinación histórica de la leyenda, es decir, su prueba, su condición de verdad aprobada. El sentido que suele otorgarse a la leyenda es a veces el de narración no verificada, pero, localizada en un espacio concreto, la creencia en lo narrado encuentra un objeto indubitable»3. Apunta esta cita al carácter especular del culto local: es el culto de los fieles la prueba de la verdad de la imagen, y no lo

3 Es algo que también subrayó André Vauchez, en la introducción de Erik Thunø et Gerhard Wolf (eds.), The Miraculous Image In the Late Middle Ages and Renaissance. Papers from a conference held at the Accademia di Danimarca in collaboration with the Bibliotheca Hertziana (Max-PlanckInstitut für Kunstgeschichte) Rome, 3 I May-2 June 2003, Roma, "L'Erma" di Bretschneider, 2004, p. Io: «En fait, l'image miraculeuse n'est pas seulement active, dans la mesure où elle effectue des miracles. Elle est surtout interactive par rapport à un spectateur ou à un public de dévots pour lesquels il est normal qu'elle intervienne en leur faveur, dès lors qu'ils la voient et la vénèrent, et qu'ils la considèrent comme un "medium" privilégié entre le monde d'ici-bas et l'au-delà. Le critère essentiel de la popularité des images miraculeuses réside en effet dans leur efficacité et le succès de certaines d'entre elles est lié, du point de vue du fidèle ou du pèlerin, au fait que le personnage qu'elles représentent se montre réceptif à la prière de ceux qui l'implorent et particulièrement disposé à l'exaucer». 
contrario. Es decir que el culto es lo que llena el hueco - la distancia- existente entre la imagen concreta, material, y la figura invisible de la Virgen.

\section{El debate sobre la imagen}

Hasta ahora, he utilizado el término de imagen sin cuestionarlo. El texto de la última sesión del concilio de Trento Sobre la invocación, veneración y reliquias de los santos, y de las sagradas imágenes parece que ha zanjado el problema de su significación afirmando su uso y su referencialidad. Pero asumiendo las posibles derivas supersticiosas criticadas por los reformados, el texto conciliar de diciembre de 1563 , negando la total identificación entre la imagen y su referente, se conformó con delegar la responsabilidad del uso ortodoxo de las imágenes a los obispos, y afirmar la capacidad didáctica de las mismas: biblia pauperum ${ }^{4}$.

Esta es la definición que da Sebastián de Covarrubias en el Tesoro de la lengua castellana (I6II), antes de pasar a recordar la separación que produce la cuestión de la imagen entre ortodoxia y heterodoxia:

Latine IMAGO, a nomine graeco eigma, tos, igma, atos, imago, similitudo. Según otros imagen dicitur quasi imitago, imago simulacrum, et alicuis rei repraesentatio. Los griegos llaman a las imágenes icones, eikon, onos, imago, según santo Tomás, I part. q. 35, art. I, ad primum: «Imago proprie dicitur quos procedit ad similitudinem alterius; id autem, a quo procedit, dicitur proprie exemplar». Comúnmente entre fieles católicos llamamos imágenes las figuras que nos representan a Cristo nuestro Señor, a su benditísima Madre y Virgen Santa María, a sus apóstoles y a los demás santos y los misterios de nuestra Fe, en cuanto pueden ser imitados y representados para que refresquemos en ellos la memoria; y que (a) la gente ruda, que no sabe lettras, les sirven de libro, como al que las sabe, la historia; y de aquí viene que los libros que tienen figuras, que significan lo que contienen cada uno y cada capítulo, se llaman libros historiados y las estampas históricas [...] (Covarrubias I998: 662).

Se constata que lo material, lo visible, en las imágenes marianas, no fue vaciado de toda verdad, de toda eficacia, a favor de lo invisible, de la vida del más allá. Al contrario de lo que puede sugerir la separación hecha por Hans

\footnotetext{
4 Citamos el texto en la traducción de Ignacio López de Ayala (El Sacrosanto y Ecuménico Concilio de Trento, I798: 355-360), «Enseñen con esmero los Obispos que por medio de las historias de nuestra Redención, expresadas en pinturas, y otras copias, se instruye y confirma al pueblo recordándoles los artículos de la fe, y recapacitándoles continuamente en ellos...Y si aconteciere que se expresen y figuren en alguna ocasión historias y narraciones de la Sagrada Escritura, por ser estas convenientes a la instrucción de la ignorante plebe, enséñese al pueblo, que esto no es copiar la divinidad, como si fuera posible que se viese esta con ojos corporales, o pudiese expresarse con colores, o figuras».
} 
Belting en su clásico Bild and Cult entre imago-simulacrum (imitación-sustitución de la verdad copiada por acción de un creador-artista) y vestigia (ruina, resto) más cercanas a lo que son las reliquias (imágenes acheiropoietas, hechas sin mano humana), las imágenes marianas permitieron expresar un modo de comprensión y de uso de la imagen que, sin negar la naturaleza material de la misma, no le quitaba tampoco su poder representativo. Veamos cómo se expresó esta idea en nuestro ejemplo paradigmático.

\section{La Virgen de los Desamparados}

La Virgen de los Desamparados es una imagen milagrosa de principios del xv cuyo culto nació dentro de una comunidad de Valencianos contemporáneos de san Vicente Ferrer, en un grupo de promotores del primer hospital de locos, el Hospital dels Ignoscents, Folls e Orats (Aparicio Olmos I964 y I968). Más concretamente, se atribuye al fraile de la Merced Juan Gilabert Jofré el haber solicitado la caridad de sus conciudadanos en un sermón del primer domingo de Cuaresma de I409. El Papa Benedicto XIII, al cual la Corona de Aragón permaneció fiel, dedicó el hospital al patrocinio de los Santos Inocentes, pero los fundadores quisieron colocarlo bajo el patrocinio de la Virgen María. Así fue cómo el hospital pasó a llamarse de «Nostra Donna Sancta María dels Innocens». Pero la imagen todavía no existía. Hubo que esperar a que la cofradía fuera fundada, lo que se produjo en I4I3, siendo esta aprobada en I4I4 por el rey de Aragón y por el Papa. Luego la cofradía pidió autorización al rey Alfonso III de Valencia (Alonso el Magnánimo) de «tener una representación o imagen de la Virgen María en plata dorada o en madera para colocarla sobre las espulturas de los miembros de la cofradía y de aquellos a quienes ofrecen sepultura». Se menciona por primera vez la imagen en los archivos de la cofradía en I426. Tiene la particularidad de tener la cabeza inclinada para poder colocarla sobre un cojín en los féretros de los cofrades. Lleva una flor de lis en la mano derecha, y el Niño Jesús lleva la cruz. Cortada por detrás, es decir plana, se la viste para las procesiones con largo manto, y se la pega a la pared de un palio cuando se la expone al culto. Pero a pesar de saber que la imagen tuvo que ser fabricada después de la creación de la cofradía, sus orígenes son legendarios.

La leyenda cuenta que el Padre Gilabert, quien ya había incitado a los Valencianos a crear el hospital de los locos de Valencia, en varios sermones pidió también que los escultores e imagineros hicieran una imagen de la Virgen María para la cofradía. Un día de I4I4, cuatro jóvenes peregrinos llegados a Valencia fueron acogidos en los edificios de la cofradía. En contrapartida ofrecieron fabricar una imagen de la Virgen en tres días, y fueron instalados en la ermita de la cofradía. Al cabo de los tres días, la ermita estaba silenciosa y los peregrinos no se habían presentado. Se forzó 
la puerta y se encontró la imagen de la Virgen María, cuya belleza, asociada con la desaparición de los peregrinos, hizo deducir que era un divino retrato de la Virgen, y que los peregrinos desaparecidos eran unos ángeles (Aparicio Olmos I964 y 1968). En definitiva, la imagen es presentada como acheiropoieta: más cercana al vestigium, a la reliquia, que al simulacrum. Pero, la forma cómo se define la imagen de la Virgen de los Desamparados es de la «materia ambigua». Esta expresión se encuentra bajo la pluma de José Vicente Ortí, autor de la Historia de la Sagrada Imagen de Maria Santissima. Indica que se le concedía a la imagen un poder que va más allá del de ser una representación recordatoria de la verdadera imagen invisible.

Es su materia, de carton tan bien labrado, que nuestro D. Lorenzo Matheu, tuvo por cierto ser dudosa: materiae ambiguitas; tal fue el primor, y habilidad del Artifice. Su estatura, de mas de siete palmos. El rostro, aunque por hermosissimo, y atractivo representa muy al vivo el Original que reyna en cuerpo, y alma en la gloria, manifiesta mas lo compassivo, y acostumbra variar sus colores, segun los sucessos, y ocasiones, que han ocurrido, y se han observado derramando sus preciosos ojos tiernas lagrimas,como que parece nos assiste, y acompaña en nuestras aflixiones (Ortí I767: I5-I6).

Llama la atención la insistencia hecha por Ortí en el rostro, los colores de la imagen, y los sentimientos que ella suscita en los espectadores-fieles. La imagen es considerada como vivo retrato, y retrato con vida. Esto explica que llegara a ser un tema de "comedias amorosas» a lo divino, en las que el retrato de la Virgen es el motor de la intriga. Se fraguó un subgénero de piezas dramáticas que hasta ahora nunca han sido examinado. La creación de este tipo de comedias religiosas no es solo una prueba del interés central que tenía el culto de las Vírgenes para los súbditos de Felipe III, Felipe IV y Carlos II (I598-I700). También se explica porque remitían estas intrigas a la relación entre copia y realidad, imitación y esencia, omnipresente en la expresión tanto literaria como plástica del Barroco español.

\section{Comedias de imágenes marianas (o de imágenes milagrosas)}

El motivo del retrato de la Virgen provoca un enamorarse de la belleza de la imagen que parece sustituirse totalmente al prototipo en unas cuantas comedias del Siglo de Oro. Poemas amorosos a lo divino, las comedias muestran cómo se enamora un personaje, masculino o femenino, de un retrato de la Virgen, hasta el punto de que su alma sea transportada. Se expresan pues las emociones del personaje, su turbación. El amor se concibe como una forma espontánea devoción: es la señal de que el personaje ha «re- 
conocido» la «divinidad» de la imagen, ha sido capaz de ver que se trataba de un verdadero retrato de la Virgen invisible.

Por ejemplo, en la tercera jornada de la comedia La Virgen de la Fuencisla, de Juan de Matos y Juan de Zavaleta, el personaje de Ester, judía, apunta a la presencia de un «no sé qué» que le añade «alma» al rostro de la Virgen. De este modo, Ester empieza a convertirse al cristianismo. Su conversión mediante la mirada es, por así decirlo, «espontánea» 5 .

Otro ejemplo es del personaje del rey Fernando III en la Virgen de los reyes de Hipólito de Vergara (I623). El objetivo de esta comedia, erróneamente atribuida a Tirso de Molina hasta fechas relativamente recientes (Iscla Rovira 1975), era apoyar el culto al rey Fernando III de Castilla, cuyo proceso de beatificación se introdujo en Roma en I628. Hipólito de Vergara, autor de la comedia, se apoyó para ello en el culto que tanto él mismo como el candidato a la santidad tenía por la Virgen de los Reyes. Cuando en I628 dio a las prensas la hagiografía del rey Fernando III, colocó su comedia al colofón, explicando en el prólogo que: «con recíproca correspondencia y estimación de su fervoroso amor, le envió (al rey Fernando) la Reina del cielo un retrato suyo por mano y ministerio de los ángeles».

La leyenda de la Virgen de los Reyes cuenta en efecto que la Virgen se le apareció al santo y que este quiso transponer su visión en una imagen material, sin conseguirlo. Finalmente unos ángeles, bajo apariencia de peregrinos, ejecutaron el «retrato». Justifica pues que la talla de la Virgen se custodie en la capilla de la catedral y se designe como un retrato de la Virgen. Otro ejemplo podría proceder de la comedia de Agustín Moreto y Jerónimo Cáncer publicada en 1670, La Virgen de la Aurora de Agustín Moreto y Jerónimo Cáncer, que por razones de largura no podremos citar. De modo general, en esta pieza como en las otras, se activa la devoción marial de un personaje y, colmo de la «mise en abîme», se procede a esta activación gracias a la intervención milagrosa de la Virgen que se representa en las tablas, a través de una apariencia, o sea de una imagen. Así es cómo Ester, logra imponer a los demás personajes el culto a la imagen mariana particular de

5 En La Virgen de la Fuencisla, de Villaviciosa, Matos Fragoso y Zabaleta, en la Jornada tercera el personaje de Ester se dirige a la imagen de María de la Fuencisla, confesando su turbación ante su «semblante» pp. 383-384: «Aunque el acaso ha sido/ el que de Roboan me ha dividido,/ a pensar he llegado,/ que del acaso se valiò el cuydado,/ pues desear no pudiera/ otra ocasion, que mas agradeciera./ La corta suerte mia,/ bellissimo Retrato de Maria,/ siempre que a tus umbrales/ passo, no sè que visos celestiales/ dulcemente me ciegan,/ que me dan luz, quando la luz me niegan,/detenerme no puedo,/ como quisiera verte, pero el miedo/ de la nota que diera/ de mi nacion, si en ti me suspendiera,/ mas oy que por la rara/ festividad ninguno en mi repara,/ con cuidadoso descuido notar quiero,/ no que vi yo mas, que vio en ti el Tercero,/ y justo Rey Fernando/ que del suelo, y de ti se fue apartando/ la atencion vehemente,/ mucho siente azia si, quien nada siente./ Respetable, y hermoso es el semblante,/ mas semblante sin alma no es bastante/ a elevar tanto un alma,/ que dexe el cuerpo en inmobil calma;/ mas alli un no sè que vè mi desvelo,/ o que del cielo baxa, o sube al cielo». 
la Fuencisla. La devoción del personaje es, en todos los casos, el motor de la acción dramática que converge hacia el culto colectivo.

El retrato es considerado aquí pues como una imagen verdadera. Dicho de otro modo, la verdad de la imagen se traduce por el término de «retrato», que es la copia exacta de un modelo, capaz de sustituirse al prototipo, y los personajes motores de la intriga lo perciben antes que los demás.

El término de «retrato» ya había sido también utilizado en la comedia de Tirso de Molina, La dama del olivar, que sería una de las primeras comedias del subgénero que aquí definimos. Es una comedia cuya redacción sitúa la editora Blanca de los Ríos en el momento de un exilio de Tirso entre agosto de I6I4 y febrero de I6I5, en el cual no ha encontrado ningún documento relativo a su presencia en Toledo. Sigue a la comedia Tanto es lo de más como lo de menos, sátira disparatada del valido de Felipe III, el duque de Lerma. La comedia forma parte, eso es indudable, del ciclo aragonés del teatro tirsiano, junto con La joya de las montañas Santa Orosia, anterior a El celoso prudente, Palabras y plumas, Los Amantes de Teruel, Quien calla otorga. Es decir que formaría parte de las comedias escritas en Aragón, durante un supuesto destierro cuya sede puede haber sido el convento mercedario de Estercuel.

Sea como fuere, en el desenlace todos los personajes de La dama del olivar se reúnen en torno al olivo santo al que Maroto, primer devoto de la Virgen -a la que le ha aparecido ya en dos circunstancias-, les ha traído. Maroto tiene la cabeza torcida. Es el resultado del milagro realizado por la Virgen para dar pruebas de que le ha efectivamente aparecido, y de que hay que creerlo cuando cuenta que ella le ha pedido que se funde un convento de mercedarios para guardar su imagen en el olivo cerca de Estercuel. La Virgen María toma la palabra después de que todos los personajes reunidos le hayan rezado. En los versos que pronuncia instituye el culto a su «retrato» particular, apelando a la construcción de un santuario para albergarlo:

Virgen. Hijos, el amor que siempre

he tenido a vuestra tierra, pues en vida a Zaragoza

ilustré con mi presencia, me obliga a que mi retrato os deje, en quien todos tengan refugio en sus aflicciones y socorro en sus miserias. Labradme en este olivar un Monasterio e Iglesia que mis hijos Redentores dichosamente posean, y haciendo el altar mayor en esta parte, por prueba de que soy paloma pura 


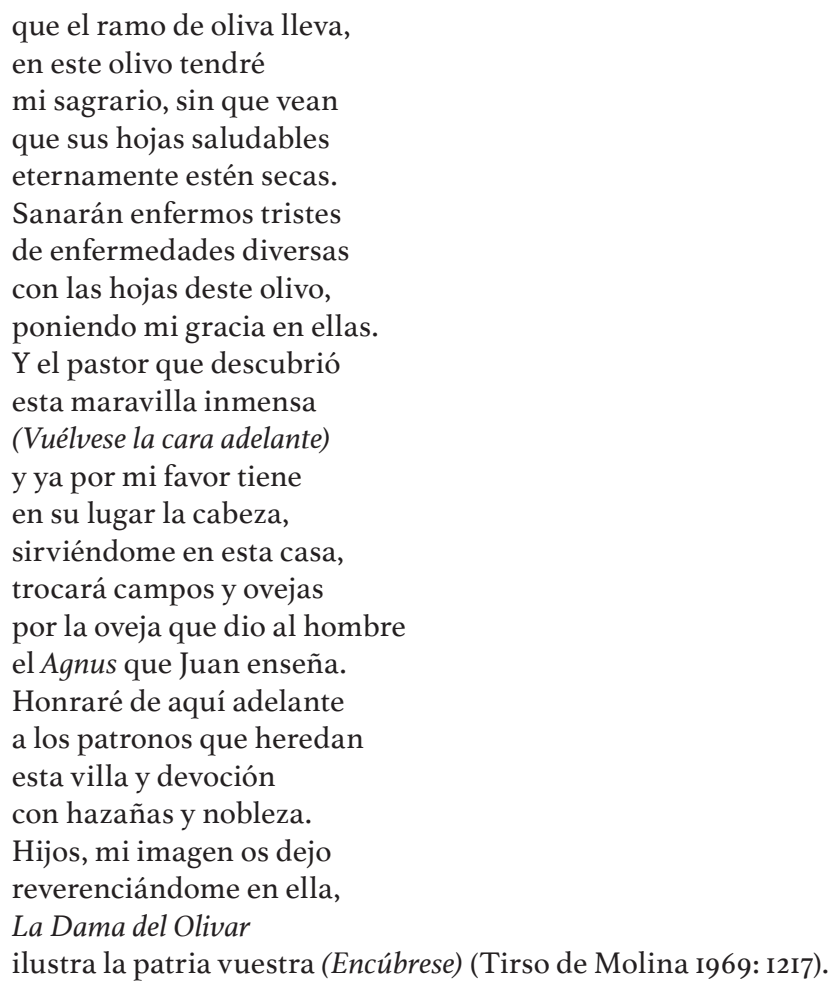

La comedia, con su estructura teleológica propia del subgénero al que pertenece, representa la institución del culto a la Virgen. Se trata de poner en escena la devoción de un grupo humano determinado. No se representa pues el culto a la Virgen de la narratio bíblica, sino su culto particular en un lugar concreto, del que se dramatiza el entorno. Los personajes de la pieza, incluso los que resisten a reconocer que la imagen sea una imagen milagrera, vienen a definirse, en este marco, como sus fieles potenciales, que ante todo son los espectadores de la talla. Al final, debe triunfar su culto. Según esta lógica estructural, el reconocimiento del retrato es un leitmotiv de este tipo de comedias, igualmente presente en La Virgen de los Desamparados de Valencia, Marco Antonio Ortíz. Si menciono este texto en particular, no es solo para corroborar una vez más la creencia en que las imágenes marianas eran retratos, copias, de la Virgen. Me importa igualmente citarla porque es el eslabón de una investigación intelectual y creativa extremadamente refinada sobre la «materia ambigua» de la imagen que tuvo muchas manifestaciones a lo largo del xvII, e insistir en que el teatro fue uno de los medios de esta investigación. Encontró una expresión particularmente refinada en el género pictórico, con el «trampantojo a lo divino», cuyo primer ejemplo se- 
ría el lienzo de la Virgen de los Desamparados ejecutado por un bodegonista, Tomás Yepes, en I644. En la segunda mitad del siglo se cultivó este tipo de representación genérica del que desconozco ejemplos fuera de España.

\section{El retrato del retrato}

La obra de Yepes se conserva hoy en día en el antecoro del monasterio de las Descalzas Reales de Madrid y representa a la Virgen de los Desamparados ya mencionada. No se sabe cómo llegó a las colecciones del convento, pero el vínculo que tuvo la comunidad de coletinas con el reino de Valencia era fuerte desde su fundación bajo patronazgo de Juana de Austria, hermana de Felipe II, a mediados del siglo XVI: la primera comunidad, que contaba con la hermana de san Francisco de Borja, era originaria de Gandía. También puede explicarse la presencia de este cuadro en las Descalzas Reales por la estrecha relación entre la Corona y el santuario de la Virgen de los Desamparados, situado cerca de la catedral de Valencia, pues los reyes, como monarcas de Aragón, ejercían su patronazgo sobre él desde su fundación en la Edad Media.

La inscripción en el papel pintado al pie del manto de la Virgen precisa: «Thomas Yepes me fecit en Valencia I644», lo cual invita a varios comentarios. Por un lado aporta la precisión de la fecha y del lugar. Por otro, manifiesta la reivindicación por el artista de la autoridad de la imagen. El caso es que este artista, Tomás Yepes, era famoso por dos características: una era su origen valenciano (lo que permite renforzar la idea de la fuerte índole local reivindicada por la pintura), y la otra era su especialización en bodegones, realizados con una técnica destinada a producir la sensación de estar en presencia de los objetos pintados (iluminación, claroscuro, puesta en escena). El cuadro de la Virgen de los Desamparados ha sido realizado con la misma técnica que sus bodegones, dotando la pintura de un aspecto hiperrealista, creando una «evidencia» fundada en la confianza en la capacidad imitativa del arte. Pérez Sánchez lo llama un «trampantojo a lo divino».

Se trata de un tipo de cuadro piadoso, que representa imágenes de devoción, generalmente escultóricas - pero en algún caso también pinturas- tal como se las venera en sus altares -dotados con frecuencia de indulgencias o privilegios señalados- acompañadas de sus accesorios, tales como cortinillas, floreros, jarrones de plata o joyas. La imagen pintada, con obsesiva realidad y clara voluntad tridimensional, consigue -y es sin duda el objetivo propuesto por el artista y sus comitentes- que quien contemple el lienzo piense -y aún sienta- que se halla en presencia de la misma efigie representada y participe, por ello, de su prodigioso efluvio (Pérez Sánchez I992: I39).

Todo parte de la creencia en la «transparencia» de la imagen, en su semejanza al modelo (o propotipo), expresada por el término «retrato» ya co- 
mentado. El retrato es posible porque se trata de representar no a la Virgen María del relato evangélico, sino a la Virgen de los Desamparados representada en su lugar. Retomando una vez más la terminología de Pérez Sánchez, se podría hablar de una composición de lugar, al modo de lo que preconizó Ignacio de Loyola en sus Ejercicios espirituales. Pero la composición de lugar aquí operada es de un tipo especial. Lo que coloca en su lugar es más bien la imagen. En efecto, la pintura de Yepes da la ilusión de estar ante la imagen verdadera en su lugar de culto ${ }^{6}$.

Se produce por lo tanto con esta pintura el mismo fenómeno estructural que el ya descrito en las comedias: estamos frente a una imagen que es físicamente real, tan real para los ojos como una escultura es real para los ojos y las manos. Lo que está en juego es el concepto de «realidad» sensible, sensorial, de la imagen no tanto esculpida como vestida, cubierta, para provocar en el espectador la experiencia de estar ante la imagen. Aquí deberíamos hacer referencia a otro libro de Didi-Huberman cuyo título indica de rondón que la reflexión atañe a la cuestión de lo que se produce cuando uno está «frente a la imagen»: Devant l'image. Question posée aux fins d'une histoire de l'art. En el caso que examinamos, se incita al espectador a orar ante esta imagen como haría un peregrino ante la imagen mariana en la capilla de Valencia, depositando un exvoto. Provoca un deseo de colocar un objeto devocional. Esta presentación toma la forma de una ofrenda.

La acumulación de exvotos, relicarios, joyas, imágenes sagradas reproducidas con detalles en el cuadro de Yepes acentúa la naturaleza inanimada de lo que está representado. Sin embargo el rostro de la Virgen y del Niño están animados. La imagen se vuelve aún más «verdadera», pues los santos rostros están como engarzados en la inmobilidad total del objeto. Por lo tanto, el término de «trampantojo» parece no adecuarse a este tipo de imagen, pues no hay «engaño». Remitiéndonos una vez más al Tesoro de Sebastián de Covarrubias, el trampantojo se entendía en el XVII como «La trampa y engaño que alguno nos hace en nuestra presencia y delante de nuestros ojos» (Covarrubias I998: 974).

6 Juan Martínez Cuesta ha dedicado un artículo titulado «Los trampantojos "a lo divino". Imágenes pictóricas de cultos marianos populares en fundaciones reales. Un caso singular: el monasterio de las Descalzas Reales de Madrid» a todos los «trampantojos a lo divino» que pueden encontrarse en el monasterio de las Descalzas. A propósito del cuadro de Yepes, dice con mucha razón: «El pintor ha decidido representar la imagen tal y como se la venera en su altar, adornada con sus mismos elementos, bajo un concepto de obsesivo realismo que busca crear el mismo efecto religioso que si el espectador estuviera ante ella. De esta forma, la pintura se convierte en algo más que un simple recordatorio ya que casi se puede pensar que ante los ojos del creyente aparece como un auténtico objeto de culto con la misma validez que la obra original» (I62), y también: «El pintor no busca emular la realidad de la obra representada en una auténtico trampantojo, sino en la representación de una imagen dentro de su contexto, de ahí el insistir en los elementos decorativos que van junto a ella: el retablo que la enmarca, los candeleros que la alumbran o las flores que la hermosean» (I63). 
Hay que recordar que hubo otros muchos ejemplos de este tipo de imágenes que reflejaba una rebuscada conciencia de la «materia ambigüa» de la que las imágenes marianas eran hechas. Francisco Rizi ejecutó un trampantojo de la Virgen del Sagrario de Toledo por encargo del capítulo de la catedral para mandarlo al capitán don Manuel de Miranda, originario de Toledo, y entonces residente en Puebla de los Ángeles (México). Hacia I680 Juan Carreño de Miranda hizo el cuadro de la Virgen de Atocha hoy conservado en el museo del Prado ${ }^{7}$.

Pero de entre todos los ejemplos posibles, el cuadro de Yepes lleva esta reflexión en pinceles a sus últimas consecuencias. En efecto no solo tiende hacia la reproducción más fiel posible de la talla valenciana, imitando todos los exvotos, relicarios, accesorios (que no son tan accesorios), según la técnica del bodegón ${ }^{8}$, sino el altar sobre el cual está colocada la Virgen con el Niño. Finalmente, donde en las tavolette o milagritos que depositan los fieles al pie de la imagen se suelen encontrar inscripciones sobre las circunstancias de la cura, encontramos la inscripción ya citada con el nombre y la fecha de ejecución del cuadro. Esta inscripción nos hace asistir a la fábrica de la imagen que se nos hace presente. De este modo se declara la potencia y la calidad milagrosa del artificio pictórico, según un proceso comparable (pero no idéntico) al del Ticiano con su famosa Piedad de I57I de la Galleria dell'Academia de Venecia, en que la Mater dolorosa con Cristo en brazos está situada en un nicho, aunque no está representada como una escultura. Yepes hace triunfar el acto de pintar como un acto de devoción que permite «reconocer» la verdad de la imagen mariana. Un colmo, tratándose de un trampantojo.

Por lo tanto, después del concilio de Trento, hubo un debate muy nutrido dentro de la Iglesia católica sobre la índole teológica de las imágenes. Se expresó en particular en las imágenes marianas de culto local, que tenían la función de representar a la Virgen María del relato evangélico, pero también tenían una identidad autónoma como esculturas con cultos locales fuertemente arraigados. Sus leyendas hacían de ellas unos objetos milagreros y milagrosos, de origen divino en algunos casos. Eran de «materia ambigua». El debate sobre estas imágenes fue de tal importancia que se plasmó en el teatro. Se creó un auténtico subgénero de comedias dedicadas a estas

7 La Virgen de Atocha, h. I68o, óleo sobre lienzo, 2I8xi48 cm, número del catálogo Po5536. En la parte inferior de la peana: «CARREÑO PIC. CAMARAE R. CAROLI II». Actualmente, depositado en el Museo de Historia de Madrid. https://www.museodelprado.es/coleccion/ obra-de-arte/la-virgen-de-atocha/2f97b75a-2328-43ec-ac3e-ef7bfo94ed27 [consultado el Io de enero de 20I8].

8 Remito también a la página web del museo del Prado para que el lector pueda apreciar la técnica y el estilo de Yepes https://www.museodelprado.es/coleccion/artista/hiepes-tomas/ eI4I256b-o8f7-447d-8866-7I4bi4469a58?searchMeta=tomas\%2ohiepes [consultado el io de enero de 2018]. 
imágenes marianas. Una de ellas se dedicó a la Virgen de los Desamparados de Valencia. Esta imagen fue paradigmática del debate, hasta el punto de provocar una investigación artística muy sofisticada en el famoso cuadro de Yepes. Desató, a su vez, la creación de un subgénero pictórico, el llamado «trampantojo a lo divino». Escritores y pintores llevaron el cuestionamiento sobre la «materia ambigua» a sus últimas consecuencias. El espectador ante ellas se pregunta qué es lo que ve, qué es lo que mira.

\section{Bibliografía}

Aguirre, Joachin de, Comedia nueva. La mejor Rosa entre espinas, y Virgen de Aranzazu, suelta, s.l, s.d, s.n.

Andrés Ordax, Salvador, «La expresión artística de los "exvotos” y los "cuadros de santuarios"», Religiosidad Popular en España, actas del Simposium, II, R.C.U. Escorial-Ma Cristina, Servicio de Publicaciones, 1997, pp. 9-27.

Aparicio Olmos, Emilio María, Del sermón del P. Jofré al breve de Juan XXIII. Madre de Desamparados é, Valencia, Ediciones Mater desertorum, I964.

- Santa María de los inocentes y desamparados en su iconografía original y sus precedentes históricos, Valencia, Servicio de estudios artísticos, Institución Alfonso el Magnánimo, Diputación provincial de Valencia, 1968.

Arranz Otero, José Luis \& Ismael Gutiérrez Pastor, «Virgen de los Desamparados de Valencia», El Mundo de Carlos V. De la España Medieval al Siglo de Oro, México, 200o, pp. 308-309.

Covarrubias, Sebastián de, Tesoro de la lengua castellana o española, ed. Martín de Riquer (I943), 4a ed. I998, Barcelona, Ed. Alta Fulla.

Didi-Huberman, Georges, Devant l'image. Question posée aux fins d'une histoire de l'art, Paris, Ed. de Minuit, 1999.

-. Ce que nous voyons, ce qui nous regarde, París, Ed. de Minuit, 1992.

El Quijote en sus trajes, exposición, comisarias Sofía Rodríguez Bernís y Rosa Pereda, Madrid, Ministerio de Cultura, 2005.

García Sanz, Ana, "Virgen de los Desamparados (I644)», en Arte y Saber. La cultura en tiempos de Felipe III y Felipe IV: exposición I5 abril-27 junio I999, Museo Nacional de Escultura, Palacio de Villena, Valladolid, Dirección General de Bellas Artes y Bienes Culturales - Secretaría de Estado de Cultura, I999, p. IOI.

—. «Virgen de los Desamparados, I644» en Ronda Kasl (ed.), Sacred Spain. Art and Belief in the Spanish World: exhibition, Indianapolis, Indianapolis Museum of Art, 2009, p. 222.

Godínez, Felipe, Comedia famosa, la Virgen de Guadalupe, suelta, Sevilla, Manuel Nicolas Vázquez, s.d. 
Graña, M. C., «La Virgen de Guadalupe: de la leyenda al teatro», en La metamorfosi e il testo: studio tematico e teatro aureo, eds. M. G. Profeti, S. Monti, F. Sandrelli, M. C. Graña [et al.], Milano, Franco Angeli, I990, pp. 77-I25. Iscla Rovira, Luis, Hipólito de Vergara autor de La reina de los reyes de Tirso de Molina. Estudio y edición crítica anotada de La Virgén de los reyes, Madrid, CSIC, 1975 .

León Marchante, Manuel de, Comedia famosa de la Virgen de la Salceda, suelta, Madrid, Alonso del Riego, s.a. [entre I700-I760].

López de Ayala, Ignacio, El Sacrosanto y Ecuménico Concilio de Trento traducido al idioma castellano por..., Madrid, Ramón Ruiz, 4a ed. I798.

Martínez Cuesta, Juan, «Los trampantojos “a lo divino”. Imágenes pictóricas de cultos marianos populares en fundaciones reales. Un caso singular: el monasterio de las Descalzas Reales de Madrid», en Religiosidad Popular en España, actas del Simposium, II, R.C.U. Escorial-M ${ }^{a}$ Cristina, Servicio de Publicaciones, I997, pp. I59-I79.

Moreto, Agustín \& Jerónimo Cáncer, La Virgen de la Aurora, en Parte treinta y quatro de comedias nuevas, escritas por los mejores ingenios de España, Madrid, Joseph Fernandez de Buendia, I670, pp. 282-3I7.

Ortí, Marco Antonio, La Virgen de los Desamparados de Valencia, Comedia famosa de Marco Antonio Ortí, suelta sin fecha, Sevilla, Francisco de Leefdael, en la Casa del Correo Viejo, s.f., s.n.

Pérez Sánchez, Alfonso Emilio, Thomas Yepes, exposición, Madrid, Fundación Bancaja, I995.

—. «Trampantojos “a lo divino”", Lecturas de historia del arte, Ephialte, 1992, 3, pp. I39-I56.

Prades, Jaime, Historia de la adoración y uso de las santas imágenes y de la imagen de la Fuente de la Salud, Valencia, Felipe Mey, I597.

Saravia, Crescenciano, «Repercusión en España del decreto del concilio de Trento sobre las imágenes», Boletín del Seminario de estudios de arte y arqueología, 26, I960, pp. I29-I43.

Tirso de Molina, La dama del Olivar, ed. Blanca de los Ríos, t. I, Madrid, Aguilar, I969, pp. II73-I2I8.

Velasco, Honorario M., «Las leyendas de hallazgos y de apariciones de imágenes. Un replanteamiento de la religiosidad popular como religiosidad local», en La Religiosidad popular, II: Vida y muerte: La imaginación religiosa, coords. Carlos Álvarez Santaló, Maria Jesús Buxó i Rey \& Salvador Rodríguez Becerra, Barcelona, Anthropos, I989, pp. 40I4IO.

Villafañe, Juan de, S.J., Compendio histórico en que se da noticia de las milagrosas y devotas imágenes de la Reina de los cielos y tierra, María Santísima, que se veneran en los más famosos santuarios de España, Madrid, I740. 
Villaviciosa, Sebastián de, Juan de Matos Fragoso \& Juan de Zavaleta, $L a$ Virgen de la Fuencisla, en Parte veinte y tres de comedias nuevas, escritas por los mejores ingenios de España, Madrid, Joseph Fernandez de Buendia, I666.

Zugasti, Miguel, «De iconografía mariana en dos comedias del Siglo de Oro: La Virgen de los Reyes de Hipólito de Vergara y La aurora en Copacabana de Calderón», en Calderón. Innovación y legado, eds. Ignacio Arellano y Germán Vega García-Luengos, Actas selectas del IX Congreso de la Asociación de Teatro Español y Novohispano en colaboración con el Grupo de Investigación Siglo de Oro de la Universidad de Navarra (Pamplona, 27 al 29 de marzo de 200o), Nueva York, Peter Lang, pp. 425-450. 